\title{
Innovative HRM. A Review of the Literature
}

\author{
Ferry Koster
}

\begin{abstract}
This research note summarizes the findings of a literature review of innovative HRM. Based on an analysis of 47 articles, three main approaches to innovative HRM are identified. First, innovative HRM can refer to innovation of HRM. Other studies focus on how HRM responds to innovations. And, thirdly, the term innovative HRM is found in the literature focusing on organizational innovativeness. These three approaches, along with theoretical explanations, are discussed. The note closes with implications for research and practice.
\end{abstract}

Submitted: April 9 $9^{\text {th }}, 2019 /$ Approved: July $2^{\text {nd }}, 2019$

\section{Introduction}

In organizations facing increasing global competition and changes in their environment, Human Resource Development (HRD) is more relevant than ever before. Such external pressures ask for employees that have the skills, knowledge, and ability to perform optimally. The facilitate that, organizations may need to apply innovative Human Resource Management (HRM) practices. By using innovative HR policies and practices, organizations aim at ensuring the autonomy and skills enhancement of employees to enable them to perform well in changing circumstances (Agarwala 2003). This means that researchers and HR managers need to have some understanding of what HRM innovation means and how it can be achieved. Prior research may be helpful for that and is reviewed in this research note, which is part of an ongoing project investigating what is known about innovative HRM and how organizations achieve it. This research note is structured as follows. First, the methodology is described. Secondly, the main results are reported. Thirdly, theoretical implications are discussed. The note closes with suggestions for research and practice.

\section{Method}

The literature review about innovative HRM was conducted in several steps. The first step was to find articles that fit the literature review. An article search was performed using scholar.google.com as the main source. Search terms that were used to find articles investigating innovative HRM are: "innovative hrm", "innovative hr practices", "innovative human resources practices", and so on. As we are interested in what organizations actually do regarding innovations related to HRM, we selected empirical studies. By including qualitative and quantitative studies we aim at generating more insights into the type of innovations that organizations apply. Hence, the selection includes articles that actually investigate innovative HRM rather than theoretical papers. Furthermore, we did not explicitly define the term innovative HRM beforehand, as part of our research focuses on the question what researchers actually mean if they are using the term. The references of the articles that this first search generated were checked and potential interesting articles were added. To assess whether these articles were indeed of interest to this literature review, a somewhat broader conception of innovative HRM was used. This means that articles focusing on organizational innovation were also scanned on terms like "human resource management" "hr practices", and so on, to ensure that no relevant articles were missed. The papers were read to assess the information they provide about innovative HRM. Selecting the ones that are published in journals that are indexed in the Social Sciences Citation Index (SSCI) assured that the review includes articles of sufficient scientific quality. This reduced the resulting list of articles. A number of papers were excluded because they did not investigate the concept of innovative HRM, even though the term was used in these articles. In these articles the term is used in a very broad sense, without specifying its content. In such articles, it is for instance stated that organizations need to apply innovative HRM practices, without explaining what is meant either with these practices or what is innovative about them. For the purpose of this article, these articles have little value. In total 47 articles remained that could be included and analyzed in the literature review (Appendix A provide the list of the articles). The articles were analyzed to find general approaches to innovative HRM.

\section{Innovative HRM}

Table 1 provides the outcomes of the analysis and summarizes the 47 articles included in the review. The table consists of three columns, namely: approach, study and subthemes. With regard to the approach to innovative HRM, three different streams of research are identified in the literature: (1) research focusing on the innovation of HRM; (2) research in which HRM is a response to (technological) innovations; and (3) research showing how HRM is linked to the innovativeness of organizations. The column labeled "studies" provides the numbers referring to the specific studies that belongs to a certain approach (the numbers correspond to the ones in Appendix A). And, in the third column several subthemes are specified, meaning that there are some differences within the three identified streams of research. Bellow, we discuss the approaches and subthemes.

${ }^{*}$ Department of Sociology, Erasmus University Rotterdam, Rotterdam, the Netherlands.

E-mail: koster@fsw.eur.nl 
Table 1. Overview of studies of innovative HRM

\begin{tabular}{l|l|l}
\hline Approach & Study & Subthemes \\
\hline & $1,2,4,5,6,10,11,12,13,14,15,16$, & a) Innovative HR policies and practices \\
Innovation of HRM & $17,18,20,21,22,23,25,26,27,28$, & b) Change of HR policies and practices \\
& $29,30,31,32,34,35,36,37,38,39$, & \\
& $40,41,43,44,45,46,47$ & \\
\hline Innovation $\rightarrow$ HRM & 3,42 & a) Technological change affects HRM \\
\hline & & b) HRM technologizes \\
\hline HRM $\rightarrow$ innovation & $2,7,8,9,19,24,33$ & a) HRM facilitates innovation \\
& & b) HRM contributing to innovation consists of innovative HR policies and practices \\
\hline
\end{tabular}

\section{Innovation of HRM}

In most of the studies the term innovative HRM refers to HR policies and practices that are considered to be innovative. Nevertheless, there is a subtle difference within this approach that needs to be taken into account. In a part of the literature, innovative HRM reflects policies and practices that are truly novel and new (in the sense of being radical innovations as they are referred to in the innovation literature, see for example Crossan and Apaydin 2010). In another part of the literature, innovative HRM is a label for change or innovation of existing policies and practices, which is a form of incremental innovation (e,g, Crossan and Apaydin 2010).

A large share of the studies aims at finding and investigating radical innovation in HRM. Most of the time, research in this field approaches the issue of innovative HRM by defining innovative HR policies and practices and then trying to measure to what extent these policies and practices are applied by organizations. Common characteristics of such innovative HR policies and practices found in the literature are:

- Equal treatment

- Human capital investments

- Sustainable employability

- Reward systems (beyond financial incentives)

- Decentralization and autonomy

A study by Agarwala (2003) serves as a good example of this approach. In this study, $14 \mathrm{HR}$ areas are distinguished, like for example, hiring policies, reward policies and developmental policies. Studies like these are related to "High Performance Work Systems" (or similar terms like HPW-organizations, HPW-practices, HIPOs, and so on) (Appelbaum, Bailey, Berg and Kalleberg 2000, Combs, Liu, Hall and Ketchen 2006). The main theoretical idea in this part of the literature is that HR policies and practices contribute to organizational performance as they increase the performance, satisfaction and commitment of employees if these policies and practices form bundles or systems. This means that the different HR policies and practices that organizations can apply, for example aimed at attracting new personnel, training employees, facilitate career paths, et cetera, need to be offered as a coherent set of instruments. What follows from this is that focusing on a single instrument is less effective than having a combination of instruments that are aimed at the same goal. According to this logic, organizations that apply instruments with contrasting goals (i.e. combining teamwork with individual pay) function poorer. What this literature furthermore shows is that to be effective, these policies and practices need to be aligned internally (they need to fit together) and aligned externally (they need to fit the organization's environment) (Huselid 1995, MacDuffie and Kochan 1995). The answer why this is more effective lies for a large part in the answer that employees are able, willing and knowing to do their work if HR instruments are aligned (Koster 2011). Having coherent systems of HR policies and practices has these motivational effects on individuals as organizations signal their expectations and goals more clearly to their employees. Hence, the level of human capital of these organizations is developed and optimized. In addition to that, organizations applying these innovative HR policies and practices are characterized by teamwork, decentralized decision making, systems enabling cooperation between units, and so forth. It should be noted that innovative HRM is a part of such high performance work systems. Besides the management of personnel, it includes a focus on the quality of supportive staff and the overall design and strategy of the organizations. Clearly, innovative HRM is an integral part of this overall strategy.

Like already noted, what we have termed the radical innovation subtheme (in the sense that organizations have these HR policies and practices or not) is a common approach in the literature on innovative HRM. The studies found here focus on the content of the practices. In a sense, it is also a static way of looking at innovative HRM, i.e., organizations apply certain practices that can be labeled innovative. Studies that fall in the second subtheme of this approach focus much more on changes, renewal and improvement of the practices that are already present in the organization. Hence, the focus is much more on incremental innovation. In that sense, it can be closely related to classical HRM themes. The research strategy that we see here is that researchers define HRM functions (selection, hiring, training, et cetera) and then ask the question whether organizations have made changes in these functional fields of HRM. What is considered a change 
is left to the respondent to decide, but the usual approach here is to ask about (significant) improvements of instruments that are already applied. The HRM of these organizations is labeled innovative if changes and improvements in these functions and their accompanying HR policies and practices have occurred.

\section{Innovations affect HRM}

While in the first stream of literature, innovation is an integral part of HRM, studies that fall in the second and third stream make a distinction between innovation and HRM. Studies in the second approach do that by regarding innovation as the independent variable. Hence, the general assumption underlying this part of the literature is that organizations adapt their HR

policies and practices in response to their external environment. Innovations (e.g. the introduction of new technologies) are part of the organizational environment and affect it. Again, two subthemes are distinguished. Here the difference between the subthemes relates to the closeness of the relation between technological innovation and HRM. In the first subtheme, in which the external innovations and HRM are two separate variables, this link is relatively weak. In the second subtheme, in contrast, this link is strong because it concerns innovations are directly applied to the HRM policies and practices of organizations.

With regard to the first subtheme in this approach to innovative HRM, there are many studies focusing on external trends and their impact on HR policies and practices. Among them are studies that have a broad view on these trends and reflect on what this means for the future of HRM. An example of this subtheme is the study by Colakoglu, Lepak and Hong (2006) who discuss how globalization and technological change affect the organizations and content of work. An even broader discussion is found in Ulrich en Dulebohn (2015). They argue that the future of HRM depends on several broad trends, namely:

- Social trends: healthcare, life style, family structures;

- Technological trends: digitalization;

- Economic trends: inflations, recessions, labor markets;

- Political trends: stability, elections;

- Environmental trends: sustainability;

- Demographic changes: age, education, diversity, income.

In this very broad approach to HRM innovation, each of these trends can be regarded as trigger for innovation. However, technological changes (along with environmental trends) reflect the link between innovation and HRM most clearly. Recent discussions about the impact of robots on the world of work neatly fit into that research. Nevertheless, the consequences for HRM remain unclear at the moment as the opinions about this impact diverge. While several authors - who are also extensively quoted in the public debate - argue that jobs will disappear (Autor, Levy and Murnane 2003, Frey and Osborne 2013), others expect that new jobs will emerge because of the introduction of robots (Brynjolfsson and McAfee 2014). Certainly, it is possible that both are true at the same time: some jobs disappear and others emerge. And, this in turn, will have consequences for HRM, for example with regards to the outflow of people, internal employability, training, hiring, and so forth. In what direction this is going in practice hugely depends on the net impact of technological developments. The same holds for the quality of work that remains. At the moment, it remains to be seen whether this involves an up-skilling or down-skilling of jobs (Van den Berge and Ter Weel 2015, Went and Kremer 2015). In both cases, there are consequences for HRM.

The second subtheme directly links innovation to HRM. Studies in line with this conceptualization of innovative HRM zoom in on the questions regarding how organizations use new technology to configure their HRM function. One of the directions found here, is that HRM itself technologizes; for instance, the application of E-HRM by organizations. E-HRM refers to the use of information technology to enable organizations to manage their human resources, for example by using web technology (Ruël, Bondarouk and Looise 2004). Whereas the idea of E-HRM has been around for a while, the number of studies focusing on it remains a minority compared to the fields identified here. Marler and Fisher (2013) provide an overview of the literature. They show that research of E-HRM is still a young field. Still, they managed to collect quite a number of studies. The main concern that they mention in their reviews is that the majority of these studies rely on a deterministic view of technology. As Marler and Fisher (2013) state this is in sharp contrast with the field of technology studies that have adopted a more complex and developmental view on the impact of technology. As processes of digitalization and the possibilities it provides for information sharing and other applications, it is likely that this field will catch up with these more general notions of the role of technology in organizations. Another field of inquiry in which HRM and technological change are closely related is that of outsourcing. Developments in information technology enable the outsourcing of HRM, meaning that some organizations rely on other parties for HR practices such as pay, but can also include training and development of employees (Greer, Youngblood and Gray 1999, Gainy and Klaas 2003). By outsourcing (part of their) HRM function, organizations can get access to technologies that are not available in their own company.

No doubt, these technological developments will continue in the future and will remain a part of the future of HRM. It may even be that it is the future of HRM. Nevertheless, whether this can be labeled a radical or an incremental innovation cannot be stated beforehand. On the one hand, it may be that the HR policies and practices remain the same and that only the means through which they are organized and who provides them changes. In that case, we can speak of an incremental innovation. If, on the other hand, the scope of E-HRM and the number of functionalities to which it gives access increases considerably, for example if they are linked to digital platforms that also serves as an external labor market, it is a much more radical innovation. 


\section{HRM contributing to innovations}

The third approach to innovative HRM reverses the link between innovation and HRM. In this part of the literature, certain HR policies and practices are regarded as supportive for or a precondition of the innovativeness of organizations. Organizational innovativeness refers to several improvements that organizations can make, such as the introduction of new products and services, applying new marketing methods or changing production and organizational processes (e.g. Crossan and Apaydin 2010, Pouwels and Koster 2017). In this approach to innovative HRM, these policies and practices are investigated as the independent variable. The kinds of HR policies and practices that are studied here range from traditional ones to the newer ones identified in the literature on high performance work systems.

Again, there are two subthemes within this approach. The studies that fall in the first subtheme are those in which researchers have a predefined idea of what constitutes HR policies and practices that contribute to the innovativeness of organizations. In their study of organizations in 32 European countries, Pouwels and Koster (2017) for example find that organizations using training and performancerelated pay score higher on product and service, market and process innovation.

The second subtheme consists of studies that are much more exploratory. Instead of defining innovative HRM beforehand, these studies leave it to the data to decide what innovative HRM is; those HR policies and practices that contribute to the innovativeness of organizations are labeled innovative.. This means that in the first subtheme there is a clear distinction between HR policies and practices on the one hand and organizational innovativeness on the other. In the second subtheme this less so, since the outcomes (innovations) are used to label the HR policies and practices. Research by Oladapo and Onyeaso (2013) serves as an example of this approach. They investigate the link between high performance work practices and organizational innovation. The 2 of the 3 dimensions of the work practices that relate to innovation are then regarded as innovative HR practices.

What is important in both subthemes is that they focus on the questions to what extent and how HRM contributes to the innovativeness of organizations, while in de other two approaches HRM is regarded as a response to (external) developments. By focusing on this aspect of HRM, these studies provide evidence for the added value of HRM.

\section{Theories and explanations}

The literature review revealed that there are at least three ways in which innovative HRM is conceptualized in the present literature. As a result, different theoretical frameworks are necessary to explain HRM innovation. Approaches 1 and 2 (innovation of HRM and innovation affects HRM) can be explained using similar theories, but approach 3 (HRM contributes to innovation) requires the use of other theoretical insights as well. Below, we discuss the most central theories under two headings: (1) Explaining the adoption of innovative HRM; and (2) Explaining how HRM contributes to innovation.

\section{Explaining the adoption of innovative HRM}

The HRM literature provides 4 general theories explaining the adoption of HR policies and practices. These are: (1) economic; (2) alignment; (3) decision-making; and (4) diffusion explanations (Subramony 2006, Koster and Wittek 2016). In the literature reviewed, each of these explanations is found. And, in some cases the studies give more than one explanation or contrast these theoretical notions.

\section{Economic explanations}

Economic explanations assume that entrepreneurs weigh benefits and costs in their decisions about the implementation of HR policies and practices. In other words, they are believed to invest in their human resources if they believe this leads to a certain pay-off (in terms of performance or other desired organizational goals, such as employee satisfaction and loyalty). An economical explanation can for example be found in the study by Sels, De Winne, Delmotte, Maes, Faems and Forrier (2006). They show that investments in HRM are related to lower levels of turnover and higher productivity.

\section{Alignment explanations}

Alignment explanations emphasize the importance of fit between the parts that constitute an organization. This means that the strategy of the organization, the technology used, its size, and so forth need to be aligned internally and the organization as a whole needs to fit its external environment. According to alignment theories these arguments also hold for HRM: the different policies and practices need to be consistent, together they need to fit the rest of the organizations and they need to be aligned to the wider organizational environment. A study by Tafti, Mithas and Krishnan (2007) is an example of this explanation. They show that organizations aim to combine HR practices that strengthen each other, while at the same time they look for ways to align these practices to the overall information-technology strategy of the organization.

\section{Decision-making explanations}

Decision-making explanations take into account that choices within organizations are the result of the actions of different actors with their own interests. This also applies to decisions that are made with regard to HRM. Rather than effectiveness and efficiency, the main mechanism in these explanations is power. The HR policies and practices that organizations apply result from a struggle among parties trying to influence the outcome. Whereas economical explanations and alignment explanations assume that the outcomes are rational and that the outcome will be the best objectively, the decision-making explanation shows that this is not necessarily the case. Research by Foster and Harris (2005) illustrates this point. They investigate how organizations device their diversity policies. They argue that having policies to increase the diversity within organizations can be beneficial to these organizations. But, at the same time, many organizations do not adopt these policies. Foster and Harris (2005) show that managers play a vital role in this process. The way in which they handle potential contradictions that can result from having diversity policies affects whether and how such policies are used. 


\section{Diffusion explanations}

Finally, diffusion explanations focus on legitimization processes. The main argument here is that by using specific HR policies and practices, organizations can be viewed as legitimate actors by others (such as financers, customers, governments and competitors). Here, the focus is on the macro level and the main question is how policies and practices within a country, region or sector diffuse. Murphy and Southey (2003) and $\mathrm{Wu}$, Bacon en Hoque (2014) are examples of studies showing how issues of legitimization help to understand these diffusion processes. In both studies external factors were vital to the diffusion of innovative HR practices. HR practitioners making decisions about adopting (innovative) HRM perceive these external factors and take them into account. One of the main reasons for adopting these HR policies and practices lies in the presence of external networks (such as business advisory networks), showing that HR practitioners may indeed seek legitimacy in these networks by adopting certain practices.

\section{Explaining how HRM contributes to innovation}

To a certain extent, it is possible to make a connection between the aforementioned theories and the approaches that link HRM and the innovativeness of organizations. For example, it can be argued that economic theories apply, because organizations apply certain practices to be able to provide innovative products or services or that allows them to be innovative in their marketing. The study by Cheng and Huand (2009) is an example of this. They argue that organizations that invest in strategic HRM are better able to manage their internal knowledge. This, in turn, has positive consequences for the extent to which these organizations are able to introduce novel innovations. In a similar manner, the other three theories may also be applied.

Besides that, there are theoretical insights that can be distilled from the general literature about innovation. For example, the Resource Based View (RBV) (Barney 1991) and Resource Dependency Theory (RDT) (Pfeffer and Salancik 1970) link the availability of unique resources within organizations to their innovativeness. These theories provide an overall explanation why having access to the valuable resources supports organizational innovation. The RBV does so by arguing that organizations that manage to exploit resources that are hard to imitate by others have a competitive advantage. Their innovativeness is part of that advantage. RDT adds that organizational innovativeness depends on the extent to which organizations create links with actors in their environment to get access to valuable resources. These general frameworks that focus on resources can also be applied to HRM since people within organizations are such resources. Developing their skills and offering ways to optimize their work effort (through learning, employability and so on) are mechanisms through which HRM can contribute to the innovativeness of organizations.

\section{Conclusion}

This research note provides an overview of the literature on innovative HRM. The main insight drawn from reviewing existing studies in this field is that innovative HRM is three distinct meanings: it may refer to innovation of HRM, HRM as a response to innovation and may be about how HRM contributes to organizational innovativeness. This insight has implications for research and for practice.
Implications for research

Having a better grip on the concept of innovative HRM helps researchers in the field to position themselves. For those interested in investigating HRM innovation, it can be helpful to formulate their research aim more sharply. Hence, Table 1 also offers a tool to decide what not to include in a study. Besides that, the overview has theoretical implications concerning innovative HRM. It should be noted that the three approaches identified in Table 1 reflect research traditions with very little overlap. This means that they have largely developed separately from each other. Hence, to date, there is very little interaction between the three approaches that are discussed in this overview. It may be worthwhile to integrate these perspectives to get a better grip on technological innovation, HRM innovation and organizational innovation. We already touched upon the difference between radical and incremental innovation, which is common in innovation research. What can be added to that is that it is possible to combine several subthemes identified here to conceptualize organizations that are radical innovators in the field of HRM. Such a conceptualization would, for example, consist of organizations developing innovative HR policies and practices as a response to innovations in their external environment to reach high levels of organizational innovativeness. Such a full integration of the three research approaches reviewed in this article is not available in the literature yet. To date, we have limited information about that, because studies either focus on the link between technological innovation and innovative HRM, as reflected in the theories discussed under the heading "Explaining the adoption of innovative HRM" or they link HRM with organizational innovativeness, following arguments presented under the heading "Explaining how HRM contributes to innovation". Theories integrating these approaches and perspectives will increase our understanding of these different kinds of innovation (technological, HRM, and organizational) and how they affect each other. One of the research questions following from such a conceptualization is what the consequences of such innovative organizations are for HR development. The present review may help researchers to expand in that direction.

Furthermore, this review shows that Human Resource Development and innovative HRM are closely connected. Much of the HR policies and practices that are found in the different parts of the literature are geared towards development. HR instruments such as training and skill enhancement are often mentioned in the articles on innovative HRM. In that sense, HRM and HRD supplement each other. Whereas HRM focuses on the policies and practices of organizations, HRD examines whether they actually lead to learning and skill enhancement of employees. With an increasing emphasis on innovative HRM the question whether the HR policies and practices have an actual effect in terms of human resource development becomes more relevant than ever before. Given that technological changes will affect the workplace now and in the near future and that organizational innovativeness remains a source of competitive advantage, research integrating innovative HRM and HRD will provide one of the core explanations of organizational performance. 
Implications for practice

For people active as HR managers, this literature review can also be of value. First, it can help them to clarify what they mean if they say that they want to be innovative. Starting from the three approaches that are identified here and the different subthemes related to them, HR practitioners should be able to have a more informed discussion about HRM innovation and how to achieve it. The studies reviewed here may serve as an inspiration for them how to design their innovative HR policies and practices. Secondly, it may also help practitioners to make informed choices about what they would like to innovate. What Table 1 also clarifies is that HRM innovation does not have to imply that organizations should always start from scratch. The three approaches can help to identify what needs the most attention in the organizations. And, in some cases adjusting existing policies and practices may be enough innovation to keep the organization and employees going.

\section{References}

Agarwala, T. 2003. "Innovative Human Resource Practices and Organizational Commitment: An Empirical Investigation.” International Journal of Human Resource Management 14 (2): 175-197

Appelbaum, E., T. Bailey, P. Berg, and A. L. Kalleberg. 2000. Manufacturing Advantage: Why High-Performance Work Systems Pay Off. Ithaca: Cornell University Press.

Autor, D., F. Levy, and R. Murnane. 2003. “The Skill Content of Recent Technological Change: An Empirical Exploration.” Quarterly Journal of Economic 11 (84): 1279-1334.

Barney, J. B. 1991. "Firm Resources and Sustained Competitive Advantage." Journal of Management 17 (1): 99-120.

Cassell, C., S. Nadin, M. Gray, and C. Clegg. 2002. "Exploring Human Resource Management Practices in Small and Medium Sized Enterprises.” Personnel Review 31 (6): 671-692.

Chen, C. J., and J. W. Huang. 2009. "Strategic Human Resource Practices and Innovation Performance. The Mediating Role of Knowledge Management Capacity." Journal of Business Research 62 (1): 104-114.

Colakoglu, S., D. P. Lepak, and Y. Hong. 2006. "Measuring HRM Effectiveness: Considering Multiple Stakeholders in a Global Context." Human Resource Management Review 16 (2): 209-218.

Combs, J., Y. Liu, A. Hall, and D. Ketchen,. 2006. "How Much do High-Performance Work Practices Matter? A Meta-Analysis of Their Effects on Organizational Performance." Personnel Psychology 59 (3): 501-528.

Crossan, M. M., and M. Apaydin. 2010. "A Multi-Dimensional Framework of Organizational Innovation: A Systematic Review of the Literature." Journal of Management Studies 47 (6): 1154-1191.
Foster, C., and L. Harris. 2005. "Easy to Say, Difficult to do: Diversity Management in Retail." Human Resource Management Journal 15 (3): 4-17.

Frey, C. B., and M. A. Osborne. 2013. The Future of Employment. How Susceptible are Jobs to Computerisation? Oxford: Oxford Martin Publication.

Gainey, T. W., and B. S. Klaas. 2013. "The Outsourcing of Training and Development: Factors Impacting Client Satisfaction." Journal of Management 29 (2): 207-229.

Greer, C. R., S. A. Youngblood, and D. A. Gray. "Human Resource Management Outsourcing: The Make or Buy Decision." Academy of Management Executive 13 (3): 85-96.

Huselid, M. A. 1995. “The Impact of Human Resource Management Practices on Turnover, Productivity, and Corporate Financial Performance." Academy of Management Journal 38 (3): 635-672.

Koster, F. 2011. "Able, Willing and Knowing. The Effects of HR Practices on Commitment and Affort in 26 European Countries." International Journal of Human Resource Management 22 (14): 2835-2851.

Koster, F., and R. P. M. Wittek. 2016. "Competition and Constraint. Economic Globalization and Human Resource Practices in 23 European Countries." Employee Relations 38 (2): 286-303.

MacDuffie, J. P., and T. A. Kochan. 1995. "Do US Firms Invest Less in Human Resources? Training in the World Auto Industry." Industrial Relations 34 (2): 147-168.

Marler, J. H., and S. L. Fisher. 2013. "An Evidence-Based Review of eHRM and Strategic Human Resource Management." Human Resource Management Review 23 (1): 18-36.

Murphy, G. D., and G. Southey. 2003. "High Performance Work Practices: Perceived Determinants of Adoption and the Role of the HR Practitioner." Personnel Review 32 (1): 73-92.

Pfeffer, J., and G. R. Salancik. 1970. The External Control of Organizations: A Resource Dependence Perspective. New York: Harper and Row.

Pouwels, I., and F. Koster. 2017. "Inter-Organizational Cooperation and Organizational Innovativeness. A Comparative Study." International Journal of Innovation Science 9 (2): 184-204.

Ruël, H., T. Bondarouk, and J. K. Looise. 2004. "E-HRM: Innovation or Irritation. An Explorative Empirical Study in Five Large Companies on Web-Based HRM." Management Revue 15 (3): 364-380.

Sels, L., S. De Winne, J. Delmotte, J. Maes, D. Faems, and A. Forrier. 2006. "Linking HRM and Small Business Performance: An Examination of the Impact of HRM Intensity on the Productivity and Financial Performance of Small Businesses." Small Business Economics 26 (1): 83-101. 
Subramony, M. 2006. "Why Organizations Adopt Some Human Resource Management Practices and Reject Others: An Exploration of Rationales." Human Resource Management 45 (2): 195-210.

Tafti, A., S. Mithas, and M. S. Krishnan. 2007. "Information Technology and the Autonomy-Control Duality: Toward a Theory." Information Technology and Management 8 (2): 147-166.

Tansky, J. W., and R. Heneman, R. 2003. "Guest Editor's Note: Introduction to the Special Issue on Human Resource Management in SMEs: A Call for More Research." Human Resource Management 42 (4): 299-302.

Ulrich, D., and J. H. Dulebohn. 2015. "Are we There Yet? What's Next for HR?” Human Resource Management Review 252: 188-204.

Van Dalen, E. J., R. Gründemann, and S. De Vries. 2003. “Onderweg naar Morgen: Ontwikkelingen en hun Betekenis voor Toekomstig HRM." Tijdschrift voor HRM 3: 63-92.
Van den Berge, W., and B. Ter Weel. 2015. "De Impact van Technologische Verandering op de Nederlandse Abeidsmarkt, 1999-2014.” In De Robot de Baas. De Toekomst van Werk in het Tweede Machinetijdperk edited by R. Went, M. Kremer and A. Knottnerus, 89-112. Den Haag/Amsterdam: WRR/Amsterdam University Press.

Went, R., and M. Kremer. 2015. Hoe we Robotisering de Baas Kunnen Blijven. Inzetten op Complementariteit. In De Robot de Baas. De Toekomst van Werk in het Tweede Machinetijdperk edited by R. Went, M. Kremer and A. Knottnerus, 23-41. Den Haag/Amsterdam: WRR/ Amsterdam University Press.

Wu, N., N. Bacon, and K. Hoque. 2014. "The Adoption of HighPerformance Work Practices in Small Businesses: The Influence of Markets, Business Characteristics and HR Expertise." International Journal of Human Resource Management 25 (8): 1149-1169. 


\section{Appendix A. Studies about innovative HRM included in the literature review}

1. Agarwala, T. 2003. "Innovative Human Resource Practices and Organizational Commitment: An Empirical Investigation.” International Journal of Human Resource Management 14 (2): 175-197.

2. Bartram, T. 2011. "Employee Management Systems and Organizational Contexts: A Population Ecology Approach.” Management Research Review 34 (6): 663-677.

3. Bell, B. S., S. W. Lee, and S. K. Yeung. 2006. "The Impact of e-HR on Professional Competence in HRM: Implications for the Development of HR Professionals." Human Resource Management 45 (3): 295-308.

4. Bondarouk, T., J. K. Looise, and B. Lempsink. 2009. "Framing the Implementation of HRM Innovation: HR Professionals vs Line Managers in a Construction Company." Personnel Review 38 (5): 472-491.

5. Cañibano, A. 2013. "Implementing Innovative HRM: Trade-Off Effects on Employee Well-Being." Management Decision 51 (3): 643-660.

6. Cassell, C., S. Nadin, M. Gray, and C. Clegg. 2002. "Exploring Human Resource Management Practices in Small and Medium Sized Enterprises." Personnel Review 31 (6): 671-692.

7. Chen, C. J., and J. W. Huang. 2009. "Strategic Human Resource Practices and Innovation Performance. The Mediating Role of Knowledge Management Capacity." Journal of Business Research 62 (1): 104-114.

8. Chen, Y., G. Tang, J. Jin, Q. Xie, and J. Li. 2014. “CEOs' Transformational Leadership and Product Innovation Performance: The Roles of Corporate Entrepreneurship and Technology Orientation." Journal of Product Innovation Management 31 (S1): 2-17.

9. De Leede, J., and J. K. Looise. 2005. "Innovation and HRM: Towards an Integrated Framework." Creativity and Innovation Management 14 (2): 108-117.

10. Decramer, A., C. Smolders, A. Vanderstraeten and J. Christiaens. 2012. "The Impact of Institutional Pressures on Employee Performance Management Systems in Higher Education in the Low Countries." British Journal of Management 23 (S1): S88-S103.

11. Eaton, S. C. 2000. "Beyond 'Unloving Care': Linking Human Resource Management and Patient Care Quality in Nursing Homes." International Journal of Human Resource Management 11 (3): 591-616.

12. Felstead, A., and D. Ashton. 2000. "Tracing the Link: Organisational Structures and Skill Demands." Human Resource Management Journal 10 (3): 5-21.
13. Foster, C., and L. Harris. 2005. "Easy to Say, Difficult to do: Diversity Management in Retail." Human Resource Management Journal 15 (3): 4-17.

14. Geary, J. F., and A. Dobbins. 2001. "Teamworking: A New Dynamic in the Pursuit of Management Control." Human Resource Management Journal 11(1): 3-23.

15. Guest, D., and N. Conway. 1999. "Peering into the Black Hole: The Downside of the New Employment Relations in the UK." British Journal of Industrial Relations 37 (3): 367-389.

16. Holden, R., V. Smith, and D. Devins. 2003. "Using 'EmployeeLed Development' to Promote Lifelong Learning in SMEs: A Research Note." Human Resource Development International 6 (1): 125-132.

17. Holtbrügge, D., C. B. Friedmann, and J. F. Puck. 2010. "Recruitment and Retention in Foreign Firms in India: A ResourceBased View." Human Resource Management 49 (3): 439-455.

18. Jain, H., M. Mathew, and A. Bedi. 2012. "HRM Innovations by Indian and Foreign MNCs Operating in India: A Survey of HR Professionals." International Journal of Human Resource Management 23 (5): 1006-1018.

19. Jiang, K., D. P. Lepak, K. Han, Y. Hong, A. Kim, and A. L. Winkler. 2012. "Clarifying the Construct of Human Resource Systems: Relating Human Resource Management to Employee Performance." Human Resource Management Review 22 (2): 73-85.

20. Jones, D. C., P. Kalmi, and A. Kauhanen. 2010. “Teams, Incentive Pay, and Productive Efficiency: Evidence from a FoodProcessing Plant." Industrial \& Labor Relations Review 63 (4): 606-626.

21. Keltner, B., and D. Finegold. 1996. "Adding Value in Banking: Human Resource Innovations for Service Firms." MIT Sloan Management Review 38 (1): 57-68.

22. Khatri, N., A. Baveja, N. M. Agrawal, and G. D. Brown. 2010. "HR and IT Capabilities and Complementarities in KnowledgeIntensive Services." International Journal of Human Resource Management 21 (15): 2889-2909.

23. Koulikoff-Souviron, M., and A. Harrison. 2010. "Evolving HR Practices in aStrategic Intra-Firm Supply Chain." Human resource management 49 (5):913-938.

24. Laursen, K., and N. J. Foss. 2003. "New Human Resource Management Practices. Complementarities and the Impact on Innovation Performance." Cambridge Journal of Economics 27: 243-263. 
25. Lengnick-Hall, M. L., C. A. Lengnick-Hall, L. S. Andrade, and B. Drake. 2009. "Strategic Human Resource Management: The Evolution of the Field." Human Resource Management Review 19 (2): 64-85.

26. MacDuffie, J. P., and T. A. Kochan. 1995. "Do US Firms Invest Less in Human Resources? Training in the World Auto Industry." Industrial Relations 34 (2): 147-168.

27. Martin-Rios, C. 2014. "Why do Firms Seek to Share Human Resource Management Knowledge? The Importance of Inter-Firm Networks." Journal of Business Research 67 (2): 190-199.

28. McDonnell, A., P. Stanton, and J. Burgess. 2011. "Multinational Enterprises in Australia: Two Decades of International Human Resource Management Research Reviewed." Asia Pacific Journal of Human Resources 49 (1): 9-35.

29. Morris, S. S., and S. A. Snell. 2011. "Intellectual Capital Configurations and Organizational Capability: An Empirical Examination of Human Resource Subunits in the Multinational Enterprise." Journal of International Business Studies 42: 805-827.

30. Muduli, A. 2015. "High Performance Work System, HRD Climate and Organisational Performance: An Empirical Study." European Journal of Training and Development 39 (3): 239-257.

31. Murphy, G. D., and G. Southey. 2003. "High Performance Work Practices: Perceived Determinants of Adoption and the Role of the HR Practitioner." Personnel Review 32 (1): 73-92.

32. Ng, I., and A. Dastmalchian. 2011. "Perceived Training Benefits and Training Bundles: A Canadian Atudy." International Journal of Human Resource Management 22 (4): 829-842.

33. Oladapo, V. and G. Onyeaso. 2013. "An Empirical Investigation of Sub Dimensions of High Performance Work Systems that Predict Organizational Innovation.” International Journal of Management and Marketing Research 6 (1): 67-79.

34. Ollier-Malaterre, A., T. McNamara, C. Matz-Costa, M. PittCatsouphes, and M. Valcour. 2013. "Looking up to Regulations, Out at Peers or Down at the Bottom Line: How Institutional Logics Affect the Prevalence of Age-Related HR Practices." Human Relations 66 (10): 1373-1395.

35. Sahdev, K., S. Vinnicombe, and S. Tyson. 1999. "Downsizing and the Changing Role of HR.” International Journal of Human Resource Management 10 (5): 906-923.

36. Sels, L., S. de Winne, S, J. Delmotte, J. Maes, D. Faems, and A. Forrier. 2006. "Linking HRM and Small Business Performance: An Examination of the Impact of HRM Intensity on the Productivity and Financial Performance of Small Businesses." Small Business Economics 26 (1): 83-101.
37. Siddique, C. M. 2004. "Job Analysis: A Strategic Human Resource Management Practice." International Journal of Human Resource Management 15 (1): 219-244.

38. Som, A. 2007. "What Drives Adoption of Innovative SHRM Practices in Indian Organizations?” International Journal of Human Resource Management 18 (5): 808-828.

39. Som, A. 2012. "Organizational Response Through Innovative HRM and Re-Design: A Comparative Study from France and India." International Journal of Human Resource Management 23 (5): 952-976.

40. Srinivasan, V., and R. Chandwani. 2014. "HRM Innovations in Rapid Growth Contexts: the Healthcare Sector in India." International Journal of Human Resource Management 25 (10): 15051525.

41. Stavrou, E. T. 2005. "Flexible Work Bundles and Organizational Competitiveness: A Cross-National Study of the European Work Context." Journal of Organizational Behavior 26 (8): 923-947.

42. Tafti, A., S. Mithas, and M. S. Krishnan. 2007. "Information Technology and the Autonomy-Control Duality: Toward a Theory." Information Technology and Management 8 (2): 147-166.

43. Wolfe, R., P. M. Wright, and D. L. Smart. 2006. "Radical HRM Innovation and Competitive Advantage: The Moneyball Story." Human Resource Management 45 (1): 111- 145.

44. Wu, N., N. Bacon, and K. Hoque. 2014. “The Adoption of High Performance Work Practices in Small Businesses: The Influence of Markets, Business Characteristics and HR Expertise." International Journal of Human Resource Management 25 (8): 11491169.

45. Zhang, M., D. Di Fan, and C. J. Zhu. 2014. "High-Performance Work Systems, Corporate Social Performance and Employee Outcomes: Exploring the Missing Links." Journal of Business Ethics 120 (3): 423-435.

46. Zheng, C., G. O’Neill, and M. Morrison. 2009. "Enhancing Chinese SME Performance Through Innovative HR Practices.” Personnel Review 38 (2): 175-194.

47. Zhou, Y., Y. Hong, and J. Liu. 2013. "Internal Commitment or External Collaboration? The Impact of Human Resource Management Systems on Firm Innovation and Performance." Human Resource Management 52 (2): 263-288. 
